\title{
Advocating Digital Literacy: Community-Based Strategies and Approaches
}

\author{
Norhasni Zainal Abiddin \\ Irmohizam Ibrahim \\ Shahrul Azuwar Abdul Aziz \\ Universiti Pertahanan Nasional Malaysia, \\ Kuala Lumpur, Malaysia
}

DOI: https://doi.org/10.36941/ajis-2022-0o18

\begin{abstract}
As the pandemic waves hit the world, digital literacy becoming more profoundly essential than ever as the world shifts its daily life towards digitalization. In addition, digital literacy skill plays a big role in the teaching and learning process. In this study, the future strategies for enhancing digital literacy for educational purposes through community development programs are being discussed. The authors analysed and reviewed diverse sources of articles, reports and documents from previous researches and works of literature. It is found that there are six main community-based strategies to enhance digital literacy to improve the learning experience, which are improving and maximizing the usage of digital infrastructure in rural areas, providing necessary digital facilities and devices for underprivileged citizens, offering attractive benefits to boost participation, conducting engaging activities and learning modules of digital literacy programs, well-trained teachers and instructors in educational institutions, and role of effective community leaders. Moving forward as the education sector moves towards digitalization, digital literacy skills will become the key role toward effective learning experience. It is recommended to all levels of community members to take part in advocating the next generations with digital literacy.
\end{abstract}

Keywords: Digital Literacy, digital skills, community development program, education post-pandemic, online learning

\section{Introduction}

Technology has become increasingly important in the lives of today's youth. Young people must be digitally literate to navigate this world efficiently. Teaching digital literacy is, undoubtedly, more important than it has ever been. Individuals are accountable according to how they utilise technology to engage with the world around them, and digital literacy is vital towards becoming digital citizens (Truesdell and Birch, 2019). There is also a growing need for developing digital literacy through leveraging a community partnership.

Meanwhile, community development is one of the crucial development frameworks in terms of development in a country. The development of each community in a country needs to be given high attention as it is related to the development of the country itself. Each community in a country has their roles and significance in driving national development in a long run. The main goal for 
community development is to upgrade and improve the quality of life of the local community to a better level, in line with the development and progress of a country. Because the context of community development has a wide scope, several aspects have become the main focus of each organization or party that organize and conduct these community development programs. There are organizations and community groups that focus on educational, economic, infrastructure and environmental development programs, eradicating poverty, raising health awareness, leadership development and various other aspects.

The Malaysia Digital Economy Corporation (MDEC) has relaunched the "\#SayaDigital Movement' in Malaysia, which was first launched in 2012 to enhance digital literacy among the B40 group (bottom 40\%), youngsters, older persons, and socioeconomically vulnerable in 12 areas across the country. The \#SayaDigital campaign was initially launched in 2020 as part of MDEC's attempts to assist Malaysians and local businesses in implementing digitization initiatives that will help to mitigate the pandemic's socioeconomic implications. The '\#SayaDigital Movement' this year focuses on three main components: educating young generations to become 'Geng \#SayaDigital' volunteers, promoting awareness through digital literacy activities, completing digital readiness evaluations, and giving community members basic digital skills training (Jean Cabico, 2021).

In today increasingly integrated social world, digital media has profound potential for instructional approaches that place learners and teachers at the centre (Aspen Institute Task Force on Learning and the Internet, 2014). Students have more choice and voice due to digital media, which enables student-directed learning a reality for most individuals (Hobbs and Coiro, 2019). So, it is important to explore how to ensure to maximize digital literacy rates among younger generations as to strive for a better learning experience.

In this article, the authors aim to explore what are the community-based digital literacy initiatives or programs around the world to promote digital literacy, especially in the education context. Besides, the authors also intend to suggest possible strategies or programs that could be conducted to advocate local communities towards a better understanding of the importance of digital literacy.

\section{Methodology}

In this study, a plethora of literature from journal articles, reports, books and also organizational websites have been reviewed and analysed to find out the possible strategies that have been carried out around the world to boost digital literacy, especially for younger generations. This is because as the world adapts to a new norm of education post-pandemic, digital literacy plays such a huge role in the learning experience. Subsequently, in conducting this document analysis and literature reviews, several electronic databases have been used such as Scopus, Wiley and Google Scholar. A few keywords such as "digital community development", "digital literacy strategies" and community development for digital literacy" were used. Meanwhile, to extend the searching process, a few other complementary techniques such as citation tracking and reference searching are used to boost the search. Then, the authors would thoroughly review and analyse the data to find the relevancy and practicality of the strategy or approach that has been discussed. Besides, the authors also explore the gap and challenges in the relevant articles. Then, the main findings related to the aim of this study were discussed. In addition, a few suggestions to improve digital literacy for educational purposes, especially in the Malaysian context were proposed.

\section{Literature Review}

\subsection{Digital Literacy}

Based on research by List (2019), it has been summarised that digital literacy is mostly discussed based on three main conceptions. The first concept is first introduced by Prensky (2001), which 
reported that digital natives are students that are born with a natural ability to use technology. "Our students today are all native speakers of the digital language of computers, video games, and the Internet," he says, coining the phrase digital natives. The new abilities that older generations have learned and honed over years of contact and practise are generally underappreciated by digital newcomers which are these younger generations of millennia. Based on empirical research, notions of today's pupils as digital natives have been questioned and disregarded (Bennett et al., 2008; Kennedy et al., 2008). As a matter of fact, despite widespread and sooner exposure to technology, younger generations of the digital era have been found to lack the requisite skills for critically evaluating internet utilisation (Li \& Ranieri, 2010), and technology exposure are unbalanced across a wide range of socio-demographic groups, contributing significantly to a "digital divide" (Hargittai \& Jennrich, 2016). Nonetheless, the idea that students are digital natives who pick up technology skills by diffusion arises in the previous literature (Jones \& Czerniewicz, 2010; Oblinger \& Oblinger, 2005). In defining a model of digital fluency, Wang et. al. (2013) propose that digital literacy is the outcome of components, including demographic features, psychological aspects and social effects, and the ability to use technology.

The second concept is that digital literacy is a compilation of interrelated abilities or competencies required for survival in the digital era, which is one of the most frequently held meanings of the term today (List, 2019). Gilster (1997) came up with the word "digital literacy," which he defined as the capability to interpret and utilise digital content in diverse forms from a variety of sources as it is presented on computers. He further explained that developing digital literacy to utilise Internet content requires learning a list of fundamental skills. While Gilster has not specified the skills which may be required for the development of digital literacy, however, Bawden (2001, 2008) identifies them as skill sets related to reading and understanding multimedia and interactive texts, assembling information, communicating information collaboratively as well as finding and critically evaluating information from digital sources. Numerous models and ontologies have contributed towards the understanding of abilities that students would require in the internet age since Gilster's proposed his competency-based concept. Eshet-Alkalai (2004) proposed a conceptual framework for digital literacy, defining it as a collection of five literacies which are reproduction literacy, information literacy, photo-visual literacy, socio-emotional literacy, and branching literacy. Students' ability for synthesizing thinking, or the ability to develop original ideas from existing information, is referred to as reproduction literacy. The skills needed in critically evaluating content online are referred to as information literacy. Photo-visual literacy is the capacity to interpret and make symbols other than text that is required for communication in the digital age. Meanwhile, socio-emotional literacy relates to the ability to communicate and collaborate online. Lastly, students' information navigation skills, or their capacity to understand between the hypertexts and multimedia sources that represent information on the Internet, are referred to as branching literacy (List, 2019).

Van Laar et al. (2017) reviewed most of the skills that are included in standard interpretations of digital literacy and relevant concepts such as new media literacy, 21st-century skills, information literacy and others else. After evaluating 75 studies, he had discovered that digital literacy and relevant components are made up of seven fundamental skills as well as five contextual skills. Contextual skills are perceived to be more strategic or facilitative of core skill application, whereas fundamental or core skills are viewed to be functional or required for accomplishing tasks. As for the core skills, there are seven components which are problem-solving, information management, critical thinking, collaboration, technical, communication and creativity. Meanwhile, for the contextual skills, the five components are made up of self-direction, adaptability, ethical awareness, life-long learning, and cultural awareness. As for the features of digital literacy, Van Laar et al. focus on critical competencies related to technology application such as technical skills, as well as cognitive skills such as critical thinking, information management, problem-solving, and also socio-emotional skills such as cultural awareness and teamwork (List, 2019).

The third conception that is actively being discussed by a lot of scholars is the sociocultural perspective on digital literacy. Sociocultural perspectives emphasise the literacy aspects of digital 
literacy and, as a result, perceive digital literacy as being associated with students' active involvement in the scope of online communities. A sociocultural view on digital literacy is defined by Knobel and Lankshear (2006) as students' involvement in socially established ways of generating, communicating, and negotiating relevant content as members of narratives through the medium of encoded texts (List, 2019).

\subsection{Community Development}

In general, community development in Malaysia has started as early as the independence years. It is a long process that involves various parties, agencies and levels of society to improve the economic, social and cultural status of the community to achieve optimal national development. Although community development efforts have been underway since 31 August 1957, pioneering programs for community development began as early as 1953 through the First Community Development Conference. The summary from the conference stated that "Community development is a movement designed to create a better life for the whole community with the active involvement and efforts of the community itself."

There are various discussions among academics and socialists in defining community development in a society. Dunham (1972) discusses the definition of community development based on several key objectives of community development which include efforts to bring about social change to increase human and material resources, strengthen institutional structures for the development, promote full engagement in society and the active participation of underprivileged people in the development process for social equality. According to Hendriks (1972), community development initiatives should concentrate on the services, including education, financial aid, agriculture, land conservation, youth welfare, erosion management, and a variety of other social services. Programs for community development has to be constantly tailored to the needs of the community. Ploch (1976) defines community development as the active involvement of local communities to improve their quality of life through the organization of various development programs. Hope (1980) states that community development is a process that starts from identifying problems that occur in society to the process of solving the problem. Hope also stated that this change should be able to be felt by the community involved with the participation of all parties such as the government, non -governmental parties and the local community itself.

For Sanders (1989), community development can be seen from four different perspectives namely processes, methods or means, programs and movements. In addition, the Community Development Academy (1997) elaborates that community development is the involvement of various parties and agencies in meeting the goal of improving the quality of life of the communities involved. The CDA also defines community development as an active and comprehensive effort by parties, directly and indirectly, involved in achieving agreed goals and objectives. In this process, an attitude of tolerance and cooperation in maximizing the use of internal resources are among some of the important elements emphasized to achieve goals in community development. Philips and Pittman (2009) define community development as a process and an outcome. The process involves the ability of the community to act collectively and improve the ability to accomplish something while the outcome involves the improvement of all physical, social and economic aspects in a community. For Fendley and Christenson (2009), the purpose of community development is to help local communities improve their more perfect social and economic living conditions. Ranjha (2013) defines community development as the process of socioeconomic improvement of the whole society and the people in the community initiated by the government authority or the organization or the community itself based on the perceived needs with maximum participation of the local population.

Dunham (1972) describes several main goals of community development which are to strengthening organisational structures for development, to seek social change for human and material improvement, and also to promote active engagement.

Likewise, based on the description of the concept of community development above, it can be 
concluded that community development is a collective and planned effort and action in every level of society to improve and enhance their quality of life for the better and achieve development in various dimensions of life. The success of community development projects and programs, involves many stakeholders, especially the government, non-governmental organizations, the private sector, the local community including the public. To carry out the community development program framework effectively, several levels of implementation methods need to be emphasized in each community development program organization. Okafor (1982) has suggested 5 stages that need to be carried out in the implementation process of community development.

- The first stage is to cultivate public awareness among the communities involved in the implementation of the program. The needs or wants of the local community are different and influenced by various factors. Therefore, the parties or communities involved in the development program to be carried out should be informed about the purpose and needs of the program and how to implement it in line with the needs of the local community.

- The second stage is to systematically analyze the existing problems. In a local community, problems and ways of solving problems are different from other communities. Parties involved in the implementation of the program must be creative and innovative in dealing with such situations and problems. Information, as well as internal and external resources, need to be utilized to achieve the goals of the program.

- The third stage is to have a trained Program Leader for every community development program. The head for each community development program plays the most important role in ensuring that each framework put in place can be implemented systematically and strategically. The appointment of project leaders should preferably be democratically appointed. This is because the selected project leader must be someone who is agreed upon and accepted among the communities involved in the program to ensure effective and convincing communication. The selected project leader must also be a person who is a leader and responsible for performing his duties.

- Next, the fourth stage is to ensure community involvement. In implementing community development programs, the community that is the focus and main goal of the program needs to be involved. This is because they need to feel that the project or program is a common right. This sense of togetherness will help increase the involvement of the community as a whole as well as increase the effectiveness of the program in developing the community.

- The fifth stage is to build confidence and relationships with outside groups. Leaders, as well as the community involved in the implementation of development programs, need to create strong self-confidence to ensure the successful implementation of these programs. In addition, building good relationships with external groups such as the government, or nongovernmental bodies and organizations or large companies can help these community development efforts achieve their goals as well as establish close cooperation between leaders and local communities.

Nowadays, especially in the Malaysian context, community development projects are the cooperation of various parties such as the government, social bodies and non-governmental organizations, as well as the local community. This is because there are programs that are planned and implemented by the government, as well as programs organized by the local community. Furthermore, there are also cooperation programs from the government and non-governmental organizations and local communities.

The development programs and approaches implemented by the government are a top-down approach while the programs and efforts carried out by the local community itself are a bottom-up approach. Both of these approaches have their respective advantages and roles in contributing to community development in Malaysia. Depending on the goals and objectives set, the programs and approaches undertaken by each party are different. These programs need to take into account various important factors in the community itself such as location, culture, religion, as well as socioeconomic 
status of the local community. Nevertheless, the main purpose of each community development program conducted is to improve the standard or quality of life of the community and the communities involved.

Non-Governmental Organizations (NGOs) also play a role as social agents to address social problems and issues that occur in the community in need. The Malaysian government has initiated an innovation policy in 2010 as well as various other initiatives in various forms of support for the success of community development programs undertaken by these non-governmental organizations. These NGOs mostly are set up by the members of the community themselves who have their missions and aims in helping the community develop in every aspect of life. There are also other smaller community groups in each locality who are also committed to supporting their community with their resources and capabilities.

\subsection{Strategies and Approaches in Advocating Digital Literacy}

Advocating people on the significance of digital literacy is a long-term and continuous process. It takes more than just government policy and effort to achieve a high digital literate community. On that note, various community development programs and initiatives have been launched and implemented in order to educate the communities on digital literacy. In this study, some diverse strategies and approaches have been done around the world, which is being discussed to gain clear insight towards effective community development programs on advocating digital literacy to future generations. Table 1 below is among the list of articles or reports that has been reviewed in this study.

Table 1: Literature Search Results

\begin{tabular}{|c|c|c|c|c|c|}
\hline Author, Year & Objectives & Country & Method & Sample & Main Findings \\
\hline $\begin{array}{l}\text { Truesdell, E., \& } \\
\text { Birch, R. (2019) }\end{array}$ & $\begin{array}{l}\text { To seek to improve the } \\
\text { knowledge of digital } \\
\text { literacy }\end{array}$ & $\begin{array}{l}\text { United } \\
\text { States of } \\
\text { America }\end{array}$ & $\begin{array}{l}\text { Mix method } \\
\text { (experimental study, } \\
\text { observations, pre- } \\
\text { and post-surveys and } \\
\text { student reflections) }\end{array}$ & $\begin{array}{l}\text { Preservice } \\
\text { teachers }\end{array}$ & $\begin{array}{l}\text { The main findings show that learners at a } \\
\text { public high school have improved their } \\
\text { knowledge and skills and have developed a } \\
\text { synergy with teachers and administration } \\
\text { through the implementation of the Three- } \\
\text { Tiered instructional model. }\end{array}$ \\
\hline $\begin{array}{l}\text { Ameen, K., \& } \\
\text { Gorman, G. E. } \\
(2009)\end{array}$ & $\begin{array}{l}\text { To find out about } \\
\text { information and digital } \\
\text { literacy (IDL) in higher } \\
\text { education }\end{array}$ & Pakistan & Literature review & \begin{tabular}{|l|} 
Pakistan \\
universities' staff \\
and students
\end{tabular} & $\begin{array}{l}\text { In Pakistan, only a very couple of university } \\
\text { libraries promote information and digital } \\
\text { literacy (IDL). It is suggested to improve formal } \\
\text { training among the higher education staff so } \\
\text { that they would be able to raise awareness on } \\
\text { digital resources to students and conduct } \\
\text { various programs to increase information and } \\
\text { digital literacy. }\end{array}$ \\
\hline \begin{tabular}{|l|} 
Kamarudin, \\
Omar, Bolong, \\
Osman, \& \\
Mahamed (2019)
\end{tabular} & $\begin{array}{l}\text { To explore the } \\
\text { initiatives toward } \\
\text { enhancing the ICT } \\
\text { usage }\end{array}$ & Malaysia & Literature review & $\begin{array}{l}\text { Rural areas } \\
\text { communities }\end{array}$ & $\begin{array}{l}\text { Promoting ICT use in rural regions through ICT } \\
\text { facilities in telecentres could aid in enhancing } \\
\text { knowledge, bridging the digital divide, } \\
\text { improving literacy, as well as improving } \\
\text { socioeconomic status. }\end{array}$ \\
\hline $\begin{array}{l}\text { Halka, M. A. A. } \\
\text { A., \& Mohamed, } \\
\text { S. (2020) }\end{array}$ & $\begin{array}{l}\text { To explore digital } \\
\text { media literacy in Jordan } \\
\text { and its challenges. }\end{array}$ & Jordan & $\begin{array}{l}\text { Literature review } \\
\text { and interviews }\end{array}$ & $\begin{array}{l}\text { Jordan and the } \\
\text { Arab population }\end{array}$ & $\begin{array}{l}\text { The Jordan Media Institute has } \\
\text { been educating instructors in media and } \\
\text { information literacy skills, in conjunction with } \\
\text { UNESCO, thus that they could pass along the } \\
\text { knowledge and skills required for students from } \\
\text { grades seven, eight, and nine in a variety of } \\
\text { educational institutions. }\end{array}$ \\
\hline $\begin{array}{l}\text { Holma, B., \& } \\
\text { Pakalna, D. } \\
(2015)\end{array}$ & $\begin{array}{l}\text { To describe the } \\
\text { information literacy of } \\
\text { people as essential } \\
\text { competencies required } \\
\text { for the generation of } \\
\text { social capital. }\end{array}$ & Latvia & \begin{tabular}{|l|} 
Mix-method \\
(Population surveys, \\
focus group \\
discussions, \\
information literacy \\
knowledge \\
assessment \\
questionnaires and \\
performing practical \\
tasks) \\
\end{tabular} & $\begin{array}{l}\text { Population of } \\
\text { Latvia }\end{array}$ & $\begin{array}{l}\text { It is indeed possible that social capital and } \\
\text { information literacy interact in a bidirectional } \\
\text { pattern. For instance, social capital may be } \\
\text { utilised to acquire access to information and } \\
\text { knowledge, while information literacy can also } \\
\text { be used to influence social capital development. }\end{array}$ \\
\hline $\begin{array}{l}\text { Hashim, A., Sidi, } \\
\text { S. H., Abubakar, }\end{array}$ & $\begin{array}{l}\text { To find out the role of } \\
\text { local NGOs in }\end{array}$ & Nigeria & Survey & $\begin{array}{l}\text { Villagers of } 20 \\
\text { villages in }\end{array}$ & $\begin{array}{l}\text { Non-governmental Organizations } \\
\text { (NGOs) contribute greatly to community }\end{array}$ \\
\hline
\end{tabular}




\begin{tabular}{|c|c|c|c|c|c|}
\hline $\begin{array}{l}\text { B. Z., Umar, B. } \\
\text { F., Aliero, H. M., } \\
\text { \& Yelwa, F. J. } \\
(2020)\end{array}$ & $\begin{array}{l}\text { community } \\
\text { development }\end{array}$ & & & $\begin{array}{l}\text { Zamfara State, } \\
\text { NGOs officials }\end{array}$ & $\begin{array}{l}\text { development in a variety of approaches, } \\
\text { including community self-help activities, such } \\
\text { as training and retraining the members of the } \\
\text { community and raising awareness and } \\
\text { sensitization in the community. it had been } \\
\text { shown that these initiatives led to lots of } \\
\text { changes, including a growth in the number of } \\
\text { children enrolled in schools. }\end{array}$ \\
\hline $\begin{array}{l}\text { Huggins, R., \& } \\
\text { Izushi, H. (2002) }\end{array}$ & $\begin{array}{l}\text { To gain a greater } \\
\text { understanding of } \\
\text { relevant and successful } \\
\text { methods of stimulating } \\
\text { an ICT culture and } \\
\text { skills development in } \\
\text { rural areas }\end{array}$ & $\begin{array}{l}\text { United } \\
\text { Kingdom }\end{array}$ & $\begin{array}{l}\text { Literature Review } \\
\text { and Interviews }\end{array}$ & UK population & $\begin{array}{l}\text { Among the strategies that are being } \\
\text { highlighted by these centres are by organizing } \\
\text { personal and educational activities as tools for } \\
\text { dissolving barriers of entry, making use of ICT } \\
\text { capabilities in the delivery of services and } \\
\text { programs as well as delivering digital and ICT } \\
\text { learning experiences beyond fixed locations. }\end{array}$ \\
\hline $\begin{array}{l}\text { Setyaningsih, R., } \\
\text { \& Utama, S. N. } \\
(2021)\end{array}$ & $\begin{array}{l}\text { To create a website as a } \\
\text { community } \\
\text { information platform }\end{array}$ & Indonesia & $\begin{array}{l}\text { System Development } \\
\text { Life Cycle method }\end{array}$ & $\begin{array}{l}\text { Villagers of } \\
\text { Biting Ponorogo }\end{array}$ & $\begin{array}{l}\text { Create a website for the community centre to } \\
\text { serve as a communication and information } \\
\text { platform. }\end{array}$ \\
\hline $\begin{array}{l}\text { Samsuddin, S. F., } \\
\text { Mohamed, N. A., } \\
\text { \& Bolong, J. } \\
\text { (2021). }\end{array}$ & $\begin{array}{l}\text { To explore the digital } \\
\text { capabilities of rural } \\
\text { communities in low } \\
\text { literacy rate areas, }\end{array}$ & Malaysia & $\begin{array}{l}\text { Quantitative method } \\
\text { and descriptive kind } \\
\text { of study using } \\
\text { questionnaires }\end{array}$ & $\begin{array}{l}\text { The rural } \\
\text { community in } \\
\text { low literacy rate } \\
\text { areas in } \\
\text { Malaysia. }\end{array}$ & $\begin{array}{l}\text { Malaysian rural populations are technologically } \\
\text { connected and well-informed. Smartphones } \\
\text { and the Internet were the most commonly } \\
\text { accessed ICT devices in the selected rural } \\
\text { villages. }\end{array}$ \\
\hline $\begin{array}{l}\text { McDougall, J., } \\
\text { Readman, M., \& } \\
\text { Wilkinson, P. } \\
(2016)\end{array}$ & $\begin{array}{l}\text { To explore the } \\
\text { impact of technology } \\
\text { on community } \\
\text { engagement, schooling, } \\
\text { and family learning } \\
\end{array}$ & $\begin{array}{l}\text { The Isle of } \\
\text { Portland }\end{array}$ & Intervention study & $\begin{array}{l}\text { Special Needs } \\
\text { Students (SEN) }\end{array}$ & $\begin{array}{l}\text { To boost participants interest to participate in } \\
\text { community development programs, attractive } \\
\text { benefits may be offered. }\end{array}$ \\
\hline $\begin{array}{l}\text { Hobbs and } \\
\text { Coiro, (2019) }\end{array}$ & $\begin{array}{l}\text { To explore the design } \\
\text { features of SIDL's } \\
\text { courses }\end{array}$ & $\begin{array}{l}\text { University } \\
\text { of Rhode } \\
\text { Island }\end{array}$ & Descriptive study & $\begin{array}{l}\text { University of } \\
\text { Rhode Island's } \\
\text { Summer } \\
\text { Institute in } \\
\text { Digital Literacy } \\
\text { (SIDL) } \\
\text { participants } \\
\end{array}$ & $\begin{array}{l}\text { Focus on how the Summer Institute in Digital } \\
\text { Literacy (SIDL) course framework emphasizes } \\
\text { the introspection of a person's objectives for } \\
\text { developing digital literacy, inquiry and } \\
\text { collaborative learning techniques, and the } \\
\text { systematic study of how educators and learners } \\
\text { personalise learning. }\end{array}$ \\
\hline $\begin{array}{l}\text { Hsu, H. P., } \\
\text { Wenting, Z., \& } \\
\text { Hughes, J. E. } \\
\text { (2018) }\end{array}$ & $\begin{array}{l}\text { To design and test a } \\
\text { pedagogical method for } \\
\text { digital } \\
\text { literacy development } \\
\text { integrating with } \\
\text { Augmented Reality. }\end{array}$ & $\begin{array}{l}\text { Northern } \\
\text { Taiwan }\end{array}$ & $\begin{array}{l}\text { Mix Method Case } \\
\text { study }\end{array}$ & $\begin{array}{l}\text { Elementary } \\
\text { students in } \\
\text { after-school } \\
\text { programs }\end{array}$ & $\begin{array}{l}\text { This research reveals statistically significant } \\
\text { improvements in five areas of students' Digital } \\
\text { Literacy practises, including information } \\
\text { management, communication and sharing, } \\
\text { cooperation, creation, evaluation and problem- } \\
\text { solving, with moderate effect sizes. }\end{array}$ \\
\hline $\begin{array}{l}\text { Horlings, L. G., } \\
\text { Roep, D., \& } \\
\text { Wellbrock, W. } \\
(2018)\end{array}$ & $\begin{array}{l}\text { To explore a selection } \\
\text { of literature on the role } \\
\text { of rural leadership }\end{array}$ & Europe & Literature review & $\begin{array}{l}\text { Sub-national } \\
\text { rural regions in } \\
\text { various } \\
\text { institutional } \\
\text { contexts in } \\
\text { Europe }\end{array}$ & $\begin{array}{l}\text { Effective rural area leadership style encourages } \\
\text { collective thinking and fosters a collaborative } \\
\text { spirit, culminating in a pattern of strategic } \\
\text { collaboration and institutional arrangements } \\
\text { that continues to evolve. }\end{array}$ \\
\hline $\begin{array}{l}\text { Rami, A. A. M., } \\
\text { Abdullah, R., \& } \\
\text { Ibrahim, A. } \\
(2016)\end{array}$ & $\begin{array}{l}\text { To find out community } \\
\text { leaders' influence as a } \\
\text { driver for rural } \\
\text { community } \\
\text { development }\end{array}$ & Malaysia & $\begin{array}{l}\text { Mix method (Survey, } \\
\text { document analysis, } \\
\text { observations and } \\
\text { interview) }\end{array}$ & $\begin{array}{l}\text { Villagers and } \\
\text { community } \\
\text { leaders in } 4 \text { rural } \\
\text { villages in } \\
\text { Terengganu }\end{array}$ & $\begin{array}{l}\text { Effective community leaders were shown to be } \\
\text { able to play a constructive role in } \\
\text { the neighbourhood as a catalyst for community } \\
\text { development. Aside from that, the } \\
\text { survey reveals that local leaders play an } \\
\text { essential role in the success of development } \\
\text { programmes. }\end{array}$ \\
\hline
\end{tabular}

\subsubsection{Improving and maximizing the usage of digital infrastructure in rural areas}

The Malaysian government shows a high priority on ICT infrastructure, as shown by the allocations made for ICT in the Eighth and Ninth Malaysia Plans. The telecentre offers rural locals' access to ICT resources like the internet and computer training space. In addition, the development of telecentres is one of the government's measures designed to raise ICT awareness among the rural locals. It has been established that allocating funds for ICT development leave a positive impact on rural communities' growth. Promoting ICT use in rural regions could aid in enhancing knowledge, bridging the digital divide, improving literacy, as well as improving socioeconomic status (Kamarudin et. al., 2019).

Rural communities play a crucial role in society as a whole because they are the centre of ideas, values, culture, and lifestyle (Tantoh \& McKay, 2020). One of the approaches that also can be 
initiated to close the gap on the digital divide is by setting up mobile computer labs. These mobile computer labs should be equipped with proper ICT facilities and professional trainers or volunteers. Various digital and ICT courses can be conducted with minimum or zero fees. Along with providing appropriate facilities to learn digital skills, this digital knowledge that is being introduced to local communities in rural villages can help improve local social and economic status.

On the other note, despite having low literacy rates, most rural areas have been reported to be technologically connected and well-informed. Smartphones and the Internet are the most commonly accessed ICT devices in the selected rural villages. It has been found that the majority of rural communities, regardless of age, able to acquire their smartphones (Samsuddin et.al., 2021). In that regard, greater awareness of digital capabilities in terms of information access and digital technology utilization among rural areas should be fostered to contribute to a greater understanding of digital technology integration and usage among rural communities. Despite that well-connected settings could not influence higher literacy rate, a more intensive approach should be introduced to ensure the ICT facilities and tools serves their purpose in bridging the gap in digital literacy rates.

Besides that, in the case of rural areas in Biting Ponogoro, Indonesia, an informative website is developed in order to boost the knowledge and information exchange to the village people (Setyaningsih \& Utama, 2021). The establishment of the local community information website intends to provide a medium of promptly and efficiently sharing information to the community. Furthermore, the establishment of a website as a community information group strives to promote digital literacy.

Nevertheless, there is still the need to establish an extended and structured plan for rural communities to enhance digital literacy to support quality education. By leveraging on telecentres as well as ICT resources that have been developed by the government, more community-based programs and events on digital literacy can be organized to maximize the functionality of these resources.

\subsubsection{Providing necessary digital facilities and devices for underprivileged citizens}

As several waves of pandemic arise over the world for these past two years, the government for most countries around the world including Malaysia have stepped up their approach towards digital literacy among citizens. As the movement control order has been issued, most sectors have switched to digitalization including the economic and education sectors. Despite many digital incentives that have been given to each citizen especially $\mathrm{B}_{40}$ and $\mathrm{M}_{40}$ citizens, there are still some challenges to pursuing this new normal culture for people with no access to digital tools as well as a lack of digital literacy skills. Because of that, it is important for each community member from a diverse background who has the same goals of bridging these digitalization challenges to gather and cooperate, so that more effective measures and programs can be implemented.

During this period of pandemic surges, corporate firms have stepped up to help these underresourced societies by providing Corporate Social Responsibility (CSR) funding to Digital Literacy initiatives such as phone donation and distribution drives, financing NGOs that provide digital access to rural villages, and many more. They have moved their focus to issues like digital literacy, and they have begun realigning and restructuring their CSR activities and employee volunteer programmes to reflect on this matter (ConnectFor, 2020).

On the other note, community resource centres become a learning space that provides opportunities for a community member to explore ICT and digital experiences. Among the strategies to attract locals to visit and participate in activities organized by these centres are by organizing personal and educational activities as tools for dissolving barriers of entry, making use of ICT capabilities in the digital and ICT services or learning programs as well as delivering digital and ICT learning experience beyond fixed locations (Huggins \& Izushi, 2002).

For instance, conducive and interactive features of a community resources centre can attract more youngers generations. It should be equipped with trendy and up-to-date technological devices 
and ICT tools to attract new people to try exploring and experiencing the digital world. Fun learning activities with hands-on experience are the main elements to consistently attract local community members to come to the centres. Besides, to boost the digital learning experience beyond the community centres, a mobile resources centre is set up to deliver IT-related training to such a rural area with no digital or ICT facilities. With meticulous planning and implementation, such an impact on digital literacy rates can be achieved.

\subsubsection{Offering attractive benefits to boost participation}

Meanwhile, an intervention project to explore the impact of technology on engagement through community services, schools and family learning has been conducted by McDougall et. al. (2015). The outcomes of this research project investigating a global technology provider's (Samsung) collaboration with a school and community on a unique island off the coast of England are discussed in his research report. A group of underprivileged and disengaged families, including students with special educational needs (SEN), were given networked mobile devices, weekly training, and an accessible 'safe space' in the form of a community-wide 'digital classroom.'

It is found that there is a lack of participation with community services in this initiative, which is much expected. However, the implementation of modern technologies and other playful communities' activities, on the other hand, was able to encourage initial participation. It is clear to say that establishing this initial relationship is a critical factor. Furthermore, before a community space can become self-sustaining through government support, particularly in the case of adult education, a certain level of constant attendance must be met. Minimal constraints for admission such as no fees, no commitments, and accessible schedules as well as immediate benefits such as fun activities, product to take away, quick skill development will be emphasized in these community spaces. However, there are also a lot of members in each community who would have shown an intrinsic motivation to improve their digital literacy abilities in areas such as fundamental IT skills, word processing, and online safety. Besides, providing access to technologies that are not commonly available, especially particularly recent technology and digital devices can increase motivation to participate in these community's development programs (McDougall et. al., 2016).

However, as well as the initial participation is important, the organisers or leaders of these communities development programs should also actively and thoroughly design appropriate program frameworks and modules to ensure a long-lasting progression and consistent participation from local community members. To ensure this, each party from local government, educational institutions, NGOs as well as local communities leaders' should collaborate to ensure effective implementation of each program.

\subsubsection{Engaging activities and learning modules of digital literacy programs}

At the University of Rhode Island's Summer Institute in Digital Literacy (SIDL), they have offered an intensive professional development course on Digital Literacy involving adult learners. The SIDL promotes evaluation on one's objectives for improving digital literacy, deepens enthusiasm for collaborative research, and focuses on how educators and learners personalize learning, among other things. Three components of this course that are being emphasized as the framework of the learning modules are a reflection on one's objectives for developing digital literacy, inquiry and collaborative learning strategies, and an examination on educators and learners personalize learning (Hobbs and Coiro, 2019).

Based on these SIDL professional development programs, this framework may also be referred to develop an extensive framework for community development programs for digital literacy. Various educational institution-community partnership digital literacy programs can be further developed by taking into account the three design features of the SIDL program.

So, the first components to be developed in every digital literacy community development 
program are to establish a clear objective or learning motivations among the participants. When it comes to engaging in various learning programs, every participant has their own set of motives. It is important to properly define one's priorities as one reflects on their motives for exploring the topic of digital literacy. Acknowledging and appreciating this difference fosters a conducive environment for co-learning (Hobbs and Coiro, 2019). Then, throughout the programs, inquiry-based projects and collaborative digital projects should be integrated into the community development programs. Throughout the process of completing the projects, active engagement and problem-solving may boost the cognitive, social and emotional aspects of digital literacy.

In addition, several studies of instructing digital literacy in the classroom have identified benefits for students who actively engage in multidimensional group projects that allow them to enhance their digital literacy by using digital tools for communication, collaborative project, creation, and problem-solving in a social, interactive setting. (Hsu et al., 2018). In addition to that, Augmented reality (AR) is a unique technology that allows users to see the real-world environment while simultaneously seeing virtual items resulting in educationally important multidimensional, contextual, and engaging representations (Dunleavy \& Dede, 2014). Many studies have attempted to improve digital literacy among students by encouraging them to use, create, and communicate digital information (Chou, Block, \& Jesness, 2012; Hagerman \& Spires, 2017). In the twenty-first century, multisensory creativity and communication are especially crucial for the development of digital literacy (Lotherington \& Jenson, 2011).

In research by Hsu et. al. (2018), a pedagogical approach is proposed that combines contextual and spiral learning approaches with Augmented Reality to aid Digital Literacy development in elementary school students. The instructional design for sequential learning tasks in a project-based learning (PBL) environment was influenced by the social constructivist for Digital Literacy framework (Reynolds, 2016) and spiral learning theory. Bruner (1960) created a spiral curriculum that emphasised a continuous deepening of a learner's knowledge of basic principles of a topic through learning to apply them in increasingly complex versions. To help learners reinforce and strengthen the complexity of learning outcomes, Bruner proposed that the curriculum should repeat these core concepts regularly while improving the level of material complexity.

So, on that note, align with the rapid growth of digitalization in teaching and learning strategies, more community development organizers should consider promoting digital literacy through augmented reality integration projects. As well as growing interest in the integration of augmented reality with other various sectors such as communication, shopping and retails and also entertainment programs, it has also recently been introduced in the education sector. As well as keeping up with the digital trend and piquing the younger generation interest to learn, it can also promote active learning among students. These augmented reality projects can be integrated with various fun activities such as making a digital personal portfolio or an animals' encyclopedia.

Non-governmental Organizations (NGOs) contribute greatly to community development in a variety of approaches, including community self-help activities, such as training and retraining the members of the community and raising awareness and sensitization in the community. it had been shown that these initiatives led to lots of changes, including a growth in the number of children enrolled in schools. Furthermore, $75.9 \%$ of NGOs indicated that they had immensely focused on training local people to recognize the positive outcomes of self-help activities. Those were passionately fostered through awareness and sensitization for self-awakening (Hashim et.al., 2020).

\subsubsection{Well-trained teachers and instructors in educational institutions}

In Pakistan, due to the scarcity of Information and Digital Literacy (IDL) instruction, there are only a few well-trained employees in libraries and other librarianship departments to execute any kind of information literacy activities. So, it has been suggested to improve formal training among the higher education staff, so that they would be able to raise awareness on digital resources to students and 
conduct various programs to increase information and digital literacy (Ameen et. al., 2009).

The lack of cultural understanding within younger generations in engaging with digital media responsibly and constructively was highlighted as a barrier to digital content literacy in Jordan, and so are the digital content literacy programmes which had been implemented and funded by external organisations. To cater for this problem, Jordan Media Institute has been educating instructors in media and information literacy skills, in conjunction with UNESCO, thus that they could pass along the knowledge and skills required for students from grades seven, eight, and nine in a variety of educational institutions (Halka \& Mohamed, 2020).

In addition, by improving professionals, graduates and educators in the aspects of digital literacy, the social capital of digital literacy generations can be produced. Information exchange and the way to access relevant knowledge are two of the most important benefits of social capital, which is directly linked to the term of information literacy. Individual information literacy is essential for an effective information transfer. It is indeed possible that social capital and information literacy interact in a bidirectional pattern. For instance, social capital may be utilised to acquire access to information and knowledge, while information literacy can also be used to influence social capital development (Holma \& Pakalna, 2015).

\subsubsection{Role of effective community leaders}

Effective leadership at the community level is a prerequisite in organizing action in society, fostering social well-being, and enhancing community viability. Undoubtedly, local leaders directly impact the lives and well-being of the local community itself. In contemporary communities and challenges, the role of local leaders and associations must be recognized as an impetus for community development (Horlings et al., 2018). Therefore, leaders who can look down and be directly involved are needed to solve complex problems, mobilize community action, improve social well-being, and increase the effectiveness of a community.

In Malaysia, the government has established Rural Development and Security Committees (MPKK) at the grassroots and rural levels to act as agents of public administration and development, especially in rural areas (Rami et al., 202ob). As a community leader, MPKK plays an important role as a formal community leader in a community. Thus, the effectiveness of MPKK leadership plays an important role in the local community in terms of socio-economic development (Rami et al., 2016). In line with its objectives, MPKK has been a driving force in various activities and programs directly related to the socio-economic development of the villagers, including carrying out their role after being given a mandate in solving development problems. In this case, they hold the power to carry out tasks assigned by government institutions including designing community development programs, planning local development, overseeing government projects, and also assisting government institutions in distributing aid to families in need.

\section{Conclusion}

From this study, the authors intend to highlight six main strategies that should be focused on to improve digital literacy to support the education post-pandemic which are; (i) improving and maximizing the usage of digital infrastructure in rural areas; (ii) providing necessary digital facilities and devices for the underprivileged citizen; (iii) offering attractive benefits to boost participation; (iv) engaging activities and learning module of digital literacy programs; (v) well-trained teachers and instructors in educational institutions; (vi) role of effective community leaders.

Therefore, digital skills and literacy are becoming one of the most important elements in the education sector, especially in the post-pandemic context. Without mastering digital skills, younger generations would face challenges to keep up with their studies. Many underprivileged students are among the most affected and left behind in their learning experience due to limited sources as well as a lack of digital literacy skills. It is also hard to only depend on teachers and educators to make effort 
in bridging this gap in students' literacy skills. On that note, local government, education institutions, corporate organizations as well as members of the local communities have to take part in this effort to promote digital literacy skills and the awareness of their importance. In addition, to optimize positive impact on the community digital literacy rates, all members of the community from the leaders, professional workers, educators as well as the younger generations themselves have to take part as much as possible in the community development programs. With a clear understanding of the objective of these programs, a major improvement in the learning experience among the younger generations as well as adult learners can be achieved.

\section{Recommendations}

It is evident from this study that the community itself play a major role in ensuring the effectiveness and consistency of the community development program in their locality. The government may have a major role in providing the basic resources and funds, but it is up to community group members to fulfil the aims and implement the strategies and framework for advocating digital literacy knowledge and skills. A few recommendations such as below are suggested to further improve future community development programs.

1. As the government put effort into improving the digital infrastructures in rural areas, NGOs may focus on helping to supply digital devices such as mobile phones or tablets for underprivileged students to help them in digital learning. Moving forward, more digital and virtual education will be implemented to adapt to the new norm in this post-pandemic era, such devices will be the main medium of education for younger generations. Without proper digital tools and skills, more students will be left behind in educations as well as more dropout cases will surge.

2. NGOs or community groups may organize digital events such as virtual training, eLearning website competitions or digital seminars or conference in order to boost the awareness and interest of community members towards digital literacy skills.

3. As for Higher Education-subscribed online databases, a formal course on digital literacy and online databases should be introduced to students as well as university staff on all levels to increase well-trained communities in academic settings. Besides, community-institutional partnership programs for promoting digital literacy skills can be organized to boost awareness and knowledge on this issue.

4. The usage of ICT facilities and services at telecentres in rural villages should be sustained and enhanced to maximize the impact of digitalization on local communities. Promotional videos and awareness campaigns on these ICT facilities can be introduced to boost people interest to participate in digital and ICT programs or events that are regularly being conducted at telecentres.

5. Besides that, it is also important to educate the local communities on sustainable community development, where the members of the communities themselves work on to develop their community with without depending on financial or resources from the government or other organizations. With a proper understanding of the need to improve themselves, they would be able to ensure their younger generations have a better quality learning experience. One of the ways of doing that is by directly involve the members of quality in every community development program in the planning stage as well as implementation stage.

6. As one of the digital approaches towards future community development programs, virtual volunteering of professional people should be promoted. This approach does not only enhance digital participation, but it may be one of the efforts in which a corporation can help local communities in ways other than simply allocating fund money. Many professional employees may volunteer virtually as teachers, mentors, and strategists, among other things, throughout this movement control phase as well as in the future. Through thorough planning and implementation, this method could help in empowering local youth and communities to collaborate consistently 
with professional individuals to continuously improve their digital literacy.

7. The government, local citizen, and other organisations should expand their support for nongovernmental organisations (NGOs). These forms of assistance should include the development of a conducive working atmosphere, as well as providing support in material, technical reports as well and financial funds.

\section{References}

Ameen, K., \& Gorman, G. E. (2009). Information and digital literacy: A stumbling block to development? A Pakistan perspective. Library Management.

Aspen Institute Task Force on Learning and the Internet. (2014). Learner at the centre of a networked world. Washington, DC: Aspen Institute. https://assets.aspeninstitute.org/content/uploads/files/content/docs/pubs/Learnerat-theCenter-of-a-Networked-World.pdf

Bawden, D. (2001). Information and digital literacies: A review of concepts. Journal of Documentation, 57(2), 218-259.

Bawden, D. (2008). Origins and concepts of digital literacy. Digital literacies: Concepts, policies and practices, $30(2008), 17-32$.

Bennett, S., Maton, K., \& Kervin, L. (2008). The 'digital natives' debate: A critical review of the evidence. British Journal of Educational Technology, 39(5), 775-786.

Bruner, J. S. (1960). The process of education. Cambridge Mass: Harvard University.

Chou, C., Block, L., \& Jesness, R. (2012). A case study of mobile learning pilot project in K-12 schools. Journal of Educational Technology Development \& Exchange, 5(2), 11-26.

Community Development Academy (CDA). (1997). Building Community from Grassroots. Columbia: University of Missouri.

ConnectFor. (2020). Digital literacy as a focus area for CSR. https://connectfor.medium.com/csr-digital-literacy205d61ee4a11

Dunham, A. (1972). Community development in North America. Community Development Journal, 7(1), 10-40. doi: $10.1093 / \mathrm{cdj} / 7.1 .10$

Dunleavy, M., \& Dede, C. (2014). Augmented reality teaching and learning. In J. M. Spector, , M. D. Merrill, , J. Elen, \& M. J. Bishop, (Eds.), Handbook of research on educational communications and technology (pp. 735745). New York, NY: Springer.

Eshet-Alkalai, Y. (2004). Digital literacy: A conceptual framework for survival skills in the digital era. Journal of Educational Multimedia and Hypermedia, 13(1), 93-106.

Fendley, K., \& Christenson, J.A. (2009). Rural reflation: An idea for community development. Journal of the Community Development Society, 20(1), 103-115.

Gilster, P. (1997). Digital literacy. New York: John Wiley.

Hagerman, M. S., \& Spires, H. (2017). A systematic review of qualitative, classroom based digital literacies research 2006-2016. In Annual Meeting of the American Educational Research Association, San Antonio, TX.

Halka, M. A. A. A., \& Mohamed, S. (2020). Digital media literacy in Jordan: Challenges and development. Education, 5(21), 34-44.

Hargittai, E., \& Jennrich, K. (2016). The online participation divide. In The communication crisis in America, and how to fix it (pp. 199-213). Palgrave Macmillan, New York.

Hashim, A., Sidi, S. H., Abubakar, B. Z., Umar, B. F., Aliero, H. M., \& Yelwa, F. J. (2020). Role of local nongovernmental organizations (NGOs) in community development in Zamfara state, Nigeria. International Journal of Environment, Agriculture and Biotechnology, 5(1).

Hendriks, G. (1972). Community development in western Europe. Community Development Journal, 7(2), 74-90. doi: $10.1093 / \mathrm{cdj} / 7 \cdot 2 \cdot 74$

Hobbs, R., \& Coiro, J. (2019). Design features of a professional development program in digital literacy. Journal of Adolescent $\mathcal{E}$ Adult Literacy, 62(4), 401-409.

Holma, B., \& Pakalna, D. (2015). Information literacy in community development. Research for Rural Development, 1, 271-276.

Hope, K. R. (1980). Social Change and rural regional Community development in the United States. Community Development Journal, 15(2), 110-116.

Horlings, L. G., Roep, D., \& Wellbrock, W. (2018). The role of leadership in place-based development and building institutional arrangements. Local Economy, 33(3), 245-268. doi: 10.1177/0269094218763050 
Hsu, H. P., Wenting, Z., \& Hughes, J. E. (2018). Developing elementary students' digital literacy through augmented reality creation: Insights from a longitudinal analysis of questionnaires, interviews, and projects. Journal of Educational Computing Research, 57(6), 1400-1435.

Huggins, R., \& Izushi, H. (2002). The digital divide and ICT learning in rural communities: Examples of good practice service delivery. Local Economy, 17(2), 111-122.

Jean Cabico. (2021). MDEC launches '\#SayaDigital Movement' to increase digital literacy across MY | MARKETECH APAC. https://marketech-apac.com/mdec-launches-sayadigital-movement-to-increase-digital-literacy-across-my/

Jones, C., \& Czerniewicz, L. (2010). Describing or debunking? The net generation and digital natives. Journal of Computer Assisted Learning, 26(5), 317-320.

Kamarudin, S. Z. O., Bolong, J., Osman, M. N., \& Mahamed, M. (2019). ICT Development of Community in Rural Areas. International Journal of Academic Research in Business and Social Sciences, 9(9).

Kennedy, G. E., Judd, T. S., Churchward, A., Gray, K., \& Krause, K. L. (2008). First year students' experiences with technology: Are they really digital natives? Australasian Journal of Educational Technology, 24(1), 108-122.

Knobel, M., \& Lankshear, C. (2006). Digital literacy and digital literacies: Policy, pedagogy and research considerations for education. Nordic Journal of digital literacy, 1(01), 12-24.

Li, Y., \& Ranieri, M. (2010). Are 'digital natives' really digitally competent? A study on Chinese teenagers. British Journal of Educational Technology, 41(6), 1029-1042.

List, A. (2019). Defining digital literacy development: An examination of pre-service teachers' beliefs. Computers $\mathcal{E}$ Education, 138, 146-158.

Lotherington, H., \& Jenson, J. (2011). Teaching multimodal and digital literacy in L2 settings: New literacies, new basics, new pedagogies. Annual Review of Applied Linguistics, 31, 226-246.

McDougall, J., Readman, M., \& Wilkinson, P. (2016). From Digital Literacy to Capability: Project Report and Impact Evaluation.

Oblinger, D., \& Oblinger, J. L. (2005). Educating the net generation. Brockport Bookshelf. http://digitalcommons.brockport.edu/bookshelf/272.

Okafor, F. (1982). Community involvement in rural development: A field study in the Bendel State of Nigeria. Community Development Journal, $17(2), 134-140$.

Phillips, R., \& Pittman, H.R. (2009). A framework for community and economic development. In. R. Phillips, \& H.R. Pittman, (Edt.), An introduction to community development (pg 3-19). New York: Routledge.

Ploch, L. A. (1976). Community development in action. Journal of Community Development Society 7(1): 5-15.

Prensky, M. (2001). Digital natives, digital immigrants part 1. On the Horizon, 9(5), 1-6.

Rami, A. A. M., Abdullah, R., \& Ibrahim, A. (2016). The community leaders as a catalyst for rural community development in the state of Terengganu. International Journal of Academic Research in Business and Social Sciences, 6(12), 2222-6990.

Rami, A. M., Aziz, F., Razali, F., \& Yusof, M. R. (2020b). Leadership and ICTs implementation for rural development. International Journal of Advanced Science and Technology, 29(7 Special Issue), 531-535.

Ranjha, A. (2013). Working practices, problems and needs of the community development projects in Punjab Province, Pakistan (Doctoral dissertation, University of Dundee).

Reynolds, R. (2016). Defining, designing for, and measuring "social constructivist digital literacy" development in learners: A proposed framework. Educational Technology Research and Development, 64(4), 735-762.

Sanders, I. T. (1989). The concept of community development. In L. J. Cary, (Edt.), Community development as a process (pp. 9-31). Missouri: University of Missouri Press.

Samsuddin, S. F., Mohamed, N. A., \& Bolong, J. (2021). Understanding the digital capabilities of rural communities in low literacy rate areas in Malaysia towards digital society. International Journal of Academic Research in Business and Social Sciences, 11(15), 174-184.

Setyaningsih, R., \& Utama, S. N. (2021). Developing Community Information Group Website to Improve Digital Literacy. In Journal of Physics: Conference Series (Vol. 1808, No. 1, p. 012016). IOP Publishing.

Tantoh, H. B., \& McKay, T. J. (2020). Rural self-empowerment: The case of small water supply management in Northwest, Cameroon. GeoJournal, 85(1), 159-171.

Truesdell, E., \& Birch, R. (2019, June). Developing Digital Literacy Through Community Engagement. In EdMedia+ Innovate Learning (pp. 1251-1254). Association for the Advancement of Computing in Education (AACE).

Van Laar, E., Van Deursen, A. J., Van Dijk, J. A., \& De Haan, J. (2017). The relation between 21st-century skills and digital skills: A systematic literature review. Computers in human behavior, 72, 577-588.

Wang, Q. E., Myers, M. D., \& Sundaram, D. (2013). Digital natives and digital immigrants. Business $\mathcal{E}$ Information Systems Engineering, 5(6), 409-419. 